\title{
Exploitation of small indigenous fish species using shore seines in three reservoirs of Sri Lanka
}

\author{
P.A.D. AJITH KUMARA AND U.S. AMARASINGHE* \\ ${ }^{1}$ National Aquatic Resources Research \& Development Agency, Crow Island, \\ Colombo 15, Sri Lanka \\ ${ }^{2}$ Department of Zoology, University of Kelaniya, Kelaniya 11600, Sri Lanka \\ *Corresponding author (E-mail: zoousa@kln.ac.lk)
}

\begin{abstract}
The fish resources in reservoirs of Sri Lanka are not efficiently harvested due to various reasons such as gear and mesh restrictions and consumer preference. However, there is a potential for augmenting reservoir fisheries production by exploiting under-exploited and unexploited fish resources in reservoirs. In the present study, an attempt was made to investigate whether shore seining could be effectively used for differential exploitation of small indigenous fish species in three Sri Lankan reservoirs. It was found that shore seining was not effective for catching all species present in reservoirs. The index of relative importance determined for fish species indicated that apart from the differences between reservoirs, their relative importance in the shore seine catches was influenced by the water level of the reservoir. It is evident from the present study that in order to establish a fishery for this under-exploited species, shore seining is the appropriate fishing strategy. However, such a fishery is needed to be strictly managed for preventing indiscriminate exploitation of exotic cichlids in Sri Lankan reservoirs, which form productive fisheries.
\end{abstract}

\section{Introduction}

In the reservoir fishery of Sri Lanka, shore seining is forbidden under the fisheries regulation of the country. This gear restriction has been imposed due to the reason that shore seining is a more efficient fishing method than gillnetting because of the indiscriminate catching of a variety of species with wide size ranges. Also, due to the presence of impediments for fishing such as submerged decaying tree stumps, shore seining is virtually impossible in most reservoirs of Sri Lanka. Shore seine nets have been reported to be in use in some reservoirs and floodplains of Sri Lanka such as Minneriya reservoir and 
Karapola villu, where submerged decaying tree stumps are absent (Fernando 1967; Amarasinghe and De Silva 1992).

The gear restrictions and mesh regulations in the gillnet fishery imposing the minimum permissible mesh size of $8.5 \mathrm{~cm}$, resulted in incomplete utilization of fisheries production in Sri Lankan reservoirs. Another reason for the dominance of Oreochromis mossambicus and $O$. niloticus contributing over $90 \%$ of the total landings in the Sri Lankan reservoir fishery is the consumer demand for these larger non-fat fish species. As stated by Pet et al. (1996), for proper management of the reservoir fishery of Sri Lanka, more complete utilization of biological fish production is imperative. It has been found that small indigenous cyprinid species such as Amblypharyngodon melettinus, Puntius chola and $P$. filamentosus which are highly abundant in Sri Lankan reservoirs, can be differentially exploited using gillnets without harming juveniles of exotic cichlids (Amarasinghe 1985; De Silva and Sirisena 1987; Pet and Piet 1993). However, so far no attempts have been made to investigate whether shore seining can be effectively used for differential exploitation of small indigenous fish species. This is of particular importance due to the well-institutionalized notion that selectivity effects of gillnets on a certain range of sizes and also its inherent characteristic of non selectiveness for the target species causing the increased 'by-catch' or catching non-target species affecting biodiversity bring about disreputation of gillnetting as a standard sampling method.

Alternatively, shore seine nets can be used to exploit small indigenous fish species which are not caught in the existing commercial fisheries of Sri Lankan reservoirs. However, it is known that tilapias exhibit depth preferences with their size and juveniles inhabit shallow littoral areas whereas adults prefer deeper, pelagic zones (Caulton and Hill 1973; Caulton 1975; Ribbink and Hill 1979). However, catch efficiencies of shore seines for certain life stages of fish depend on the mesh size as smaller individuals can escape through the mesh. It can therefore be hypothesized that some species whose selectivity patterns are different from tilapia juveniles for certain mesh sizes of shore seine nets, can be exploited by shore seining. In this paper, an attempt is made to investigate whether shore seine nets of different mesh sizes can be used to exploit small indigenous fish species without harming tilapia populations in three Sri Lankan reservoirs.

\section{Materials and Methods}

Studies were conducted in Minneriya $\left(8^{\circ} 02^{\prime} \mathrm{N} ; 80^{\circ} 53^{\prime}\right.$ E) and Udawalawe $\left(6^{\circ} 27^{\prime} \mathrm{N}\right.$; $\left.80^{\circ} 50^{\prime} \mathrm{E}\right)$, two lowland reservoirs of Sri Lanka. The sampling was performed using shore seines in the littoral zones of the three reservoirs and shore seine nets of three mesh sizes $(1 \mathrm{~mm}, 5 \mathrm{~mm}$ and $7 \mathrm{~mm}$ ) were used. The length of the seine net of $1 \mathrm{~mm}$ mesh size was $8.5 \mathrm{~m}$ and the height was $1 \mathrm{~m}$. The length and height of the seine net of $5 \mathrm{~mm}$ mesh size were $25 \mathrm{~m}$ and $1.9 \mathrm{~m}$ respectively. The $7 \mathrm{~mm}$ mesh seine net was of $50 \mathrm{~m}$ length and $2.3 \mathrm{~m}$ height. The floats fixed to the head rope and the lead sinkers of the 
bottom rope facilitated the operation of the nets which was performed by four persons. In Minneriya reservoir, 13 fishing trials were carried out from August 1998 to January 2001. In Udawalawe reservoir too, 13 fishing trials were carried out from September 1998 to May 2000. In Victoria, 14 fishing trials were carried out from October 1998 to June 2000. On each field visit, there were 3-4 sampling dates on which 2 to 6 fishing trials were carried out using seine nets of each mesh size in different locations of inshore area of each reservoir, depending on the bottom characteristics and absence of impediments to shore seining.

Catch per unit effort (CPUE) values, expressed as numbers (CPUE in numbers) and weight (CPUE in weight) per net per fishing operation, were estimated for each species caught in the shore seines.

As a measure of relative abundance and commonness of each species in the catches of shore seines, an index of relative importance (IRI), which was calculated as follows (Kolding and Skaalevik 2007), was used:

$$
\% \text { IRI }_{j}=\frac{\left(\% \mathrm{CPUE}_{\mathrm{w}_{\mathrm{j}}}+\% \mathrm{CPUE}_{\mathrm{N}_{\mathrm{j}}}\right) \mathrm{F}_{\mathrm{j}}}{\sum_{\mathrm{j}=1}^{\mathrm{m}}\left[\left(\% \mathrm{CPUE}_{\mathrm{w}}+\% \mathrm{CPUE}_{\mathrm{Nj}}\right) \mathrm{F}_{\mathrm{j}}\right]} \times 100
$$

where $\% \mathrm{IRI}_{\mathrm{j}}$ is the percentage index of relative importance for species $\mathrm{j}$ and, $\% \mathrm{CPUE}_{\mathrm{Wj}}$ and $\% \mathrm{CPUE}_{\mathrm{Nj}}$ are percentage CPUE in weight and in number respectively of species $j . F_{j}$ is percentage frequency of occurrence of species $j$ in total number of fishing trials and $\mathrm{m}$ is total number of species. IRI values were estimated for each species caught in shore seines separately for the months of high water level and low water level in the three reservoirs.

\section{Results}

Fish species caught in experimental shore seining and experimental multi-mesh gillnet fishing trials that were carried out as a parallel study (Ajith Kumara et al., in press) in the three reservoirs are given in Table 1. These results indicate that shore seining is not effective for catching all species present in the reservoir fish communities.

The percentage index of relative importance (\%IRI) of each species caught in shore seine nets during the months of high water level and low water level in the three reservoirs are given in Table 2. Althoughmblypharyngodon melettinus registered as the most important species according to \% IRI in the small mesh (12.5 mm to $37 \mathrm{~mm}$ ) gillnets (Ajith Kumara et al. in press), \% IRI of fish species in shore seine catches in all three reservoirs ranked $A$. melettinus as the second or lower important species (Table 2).Hyporhamphus limbatus was insignificant in terms of \% IRI in small mesh gillnet catches (Ajith Kumara et al., in press) but in the two reservoirs where this species is present, \% IRI of shore seine catches suggest that it is the most important fish species. The relative importance of fish species in the shore seine catches is also influenced by the water level of the reservoir (Table 2). 
Table 1. Fish species caught in experimental fishing trials with gillnets and shore seine nets in three reservoirs. + - Species caught in shore seine nets; N Species not caught in shore seine nets; A - Species not caught in any of the fishing trials.

\begin{tabular}{|c|c|c|c|}
\hline Family/species & Minneriya & Udawalawe & Victoria \\
\hline \multicolumn{4}{|l|}{ Cyprinidae } \\
\hline Amblypharyngodon melettinus (V al.) & + & + & + \\
\hline Catla catla (Ham.-Buch.) & A & $\mathrm{N}$ & A \\
\hline Chela laubuca (Ham.) & + & A & A \\
\hline Danio malabaricus (Jerdon) & + & $\mathrm{N}$ & + \\
\hline Esomus danrica (V al.) & + & A & + \\
\hline Garra ceylonensis Bleeker & $\mathrm{N}$ & A & A \\
\hline Labeo dussumieri (Val.) & $\mathrm{N}$ & + & A \\
\hline L. rohita (Ham.) & A & $\mathrm{N}$ & A \\
\hline Puntius bimaculatus (Bleeker) & + & $\mathrm{A}$ & A \\
\hline P. chola (Ham.-Buch.) & + & $\mathrm{N}$ & + \\
\hline P. dorsalis (Jerdon) & + & + & + \\
\hline P. filamentosus (V al.) & + & + & + \\
\hline P. sarana (Ham.-Buch.) & + & A & $\mathrm{N}$ \\
\hline$P$. vittatus Day & + & A & A \\
\hline Rasbora daniconius (Ham.-Buch.) & + & + & + \\
\hline Tor khudree(Sykes) & A & A & $\mathrm{N}$ \\
\hline \multicolumn{4}{|l|}{ Bagridae } \\
\hline Mystus keletius (Val.) & $\mathrm{N}$ & $\mathrm{N}$ & A \\
\hline M. vittatus (Bloch) & $\mathrm{N}$ & $\mathrm{N}$ & $\mathrm{N}$ \\
\hline \multicolumn{4}{|l|}{ Cichlidae } \\
\hline Etroplus maculatus (Bloch) & + & A & $\mathrm{N}$ \\
\hline E. suratensis (Bloch) & + & + & + \\
\hline Oreochromis mossambicus (Peters) & + & $\mathrm{N}$ & + \\
\hline O. niloticus (L.) & + & + & + \\
\hline Tilapia rendalli (Boulenger) & + & + & + \\
\hline \multicolumn{4}{|l|}{ Gobiidae } \\
\hline Glossogobius giuris (Ham.-Buch.) & + & + & + \\
\hline \multicolumn{4}{|l|}{ Hemirhamphidae } \\
\hline Hyporhamphus limbatus (V al.) & + & + & A \\
\hline \multicolumn{4}{|l|}{ Anabantidae } \\
\hline Anabas testudineus (Bloch) & $\mathrm{N}$ & $\mathrm{A}$ & A \\
\hline \multicolumn{4}{|l|}{ Siluridae } \\
\hline Ompok bimaculatus (Bloch) & $\mathrm{N}$ & $\mathrm{N}$ & $\mathrm{A}$ \\
\hline \multicolumn{4}{|l|}{ Mastacembelidae } \\
\hline Mastacembelus armatus (Lacapede) & $\mathrm{N}$ & $\mathrm{A}$ & $\mathrm{N}$ \\
\hline \multicolumn{4}{|l|}{ Ophicephalidae } \\
\hline Ophicephalus striatus (Bloch) & + & A & $\mathrm{A}$ \\
\hline \multicolumn{4}{|l|}{ Osphronemidae } \\
\hline Trichogaster pectoralis (Regan) & + & A & A \\
\hline \multicolumn{4}{|l|}{ Heteropneustidae } \\
\hline Heteropneustes fossilis (Bloch) & $\mathrm{N}$ & + & $\mathrm{N}$ \\
\hline Number of species present & 28 & 19 & 18 \\
\hline Number of species caught in shore seines & 20 & 11 & 12 \\
\hline Percentage caught in shore seines & 71.4 & 57.9 & 66.7 \\
\hline
\end{tabular}


Table 2. Percentage index of relative importance (\% IRI) of fish species caught in shore seines during the seasons of high water (HW) and low water (LW) in three reservoirs.

\begin{tabular}{lllllll}
\hline \multirow{2}{*}{ Species } & \multicolumn{7}{c}{ \% IRI } \\
\cline { 2 - 7 } & \multicolumn{7}{c}{ Minneriya } & Udawalawe & Victoria \\
\cline { 2 - 7 } & HW & LW & HW & LW & HW & LW \\
\hline Amblypharyngodon melettinus & 9.9 & 1.1 & 13.0 & 18.0 & 17.0 & 26.9 \\
Chela laubuca & 3.7 & 7.9 & - & - & - & - \\
Danio malabaricus & 0.6 & 0.1 & - & - & 37.1 & 27.9 \\
Esomus danrica & 0.3 & 0.4 & - & - & 0.2 & 2.0 \\
Etroplus maculatus & 3.1 & 10.0 & - & - & - & - \\
Etroplus suratensis & 1.0 & 0.6 & 6.5 & 9.4 & - & 0.2 \\
Glossogobius giuris & 0.7 & 1.4 & 0.9 & 0.6 & 1.2 & 2.9 \\
Heteropneustes fossilis & - & - & - & 0.1 & - & - \\
Hyporhamphus limbatus & 32.8 & 49.5 & 48.3 & 51.8 & - & - \\
Labeo dussumieri & - & - & - & 0.1 & - & - \\
Oreochromis mossambicus & 0.3 & 0.6 & - & - & - & 0.8 \\
O. niloticus & 2.0 & 5.3 & - & 2.8 & 0.8 & 0.1 \\
Ophicephalus striatus & - & 0.3 & - & - & - & - \\
Puntius bimaculatus & 0.1 & - & - & - & - & - \\
P. chola & 0.2 & 0.1 & - & - & 0.1 & 0.4 \\
P. dorsalis & 0.7 & - & 0.6 & 0.3 & - & 0.1 \\
P. filamentosus & 7.3 & 6.0 & 21.3 & 5.6 & 41.5 & 32.5 \\
P. sarana & 0.1 & - & - & - & - & - \\
P. vittatus & - & 0.6 & - & - & - & - \\
Rasbora daniconius & 35.4 & 12.8 & 7.6 & 1.5 & - & - \\
Tilapia rendalli & 2.1 & 3.2 & 1.7 & 4.4 & 2.1 & 6.2 \\
\hline & & & & & & \\
\hline
\end{tabular}

The relative abundance and \% frequency of different species in shore seine catches during the months of high water level and low water level showed drastic differences in all three reservoirs (Figures 1 to 3). In Minneriya reservoir, both Rasbora daniconius and $H$. limbatus were of equal dominance during the months of high water level (Figure 1a). However, during the months of low water level in the same reservoir, $H$. limbatus showed much higher dominance in the shore seine catches (Figure 1b). In Udawalawe $H$. limbatus ranked as the most dominant species in both seasons (Figures $2 \mathrm{a}$ and $2 \mathrm{~b}$ ), but the second dominant species was Puntius filamentosus during the months of high water level (Figure 2a) whereas $A$. melettinus ranked as the second during the months of low water level (Figure 2b). The three most dominant species ( $P$. filamentosus, Danio malabaricus and A. melettinus) in the shore seine catches in Victoria reservoir remained the same during both seasons (Figures $3 a$ and $3 b$ ). 

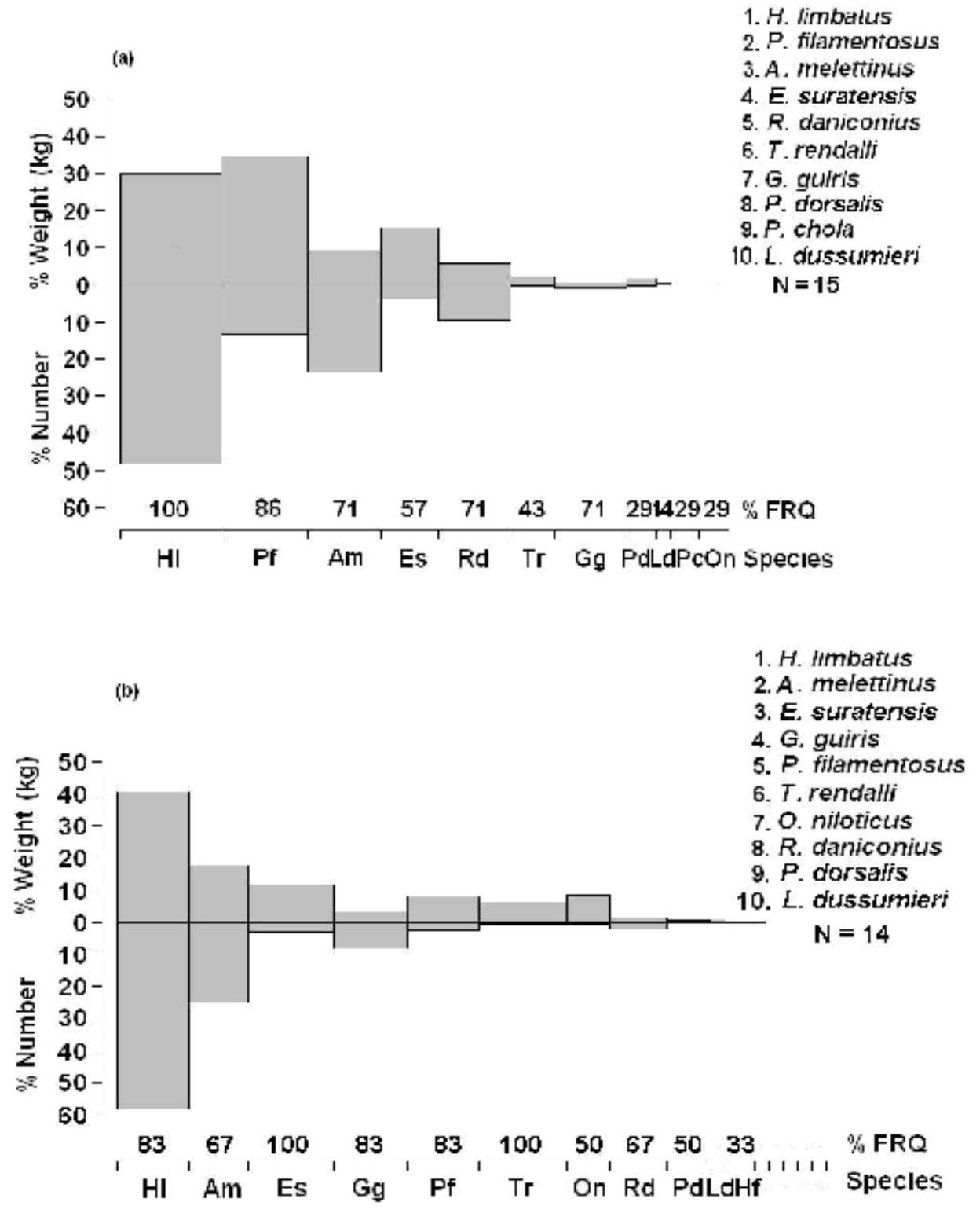

Figure 1. Relative importance of the fish species caught in shore seine nets during the seasons of high and low water level in Minneriya reservoir. The ten most dominant fish species in the catches are listed in each figure. (a) High water level; (b) Low water level; Weight (\%) - \% CPUE; Number (\%) - \% $\mathrm{CPUE}_{\mathrm{N}} ; \% \mathrm{FRQ}-\%$ Frequency of occurrence; $\mathrm{N}$ - Number of species. For explanation of notations and terms, see the text. 

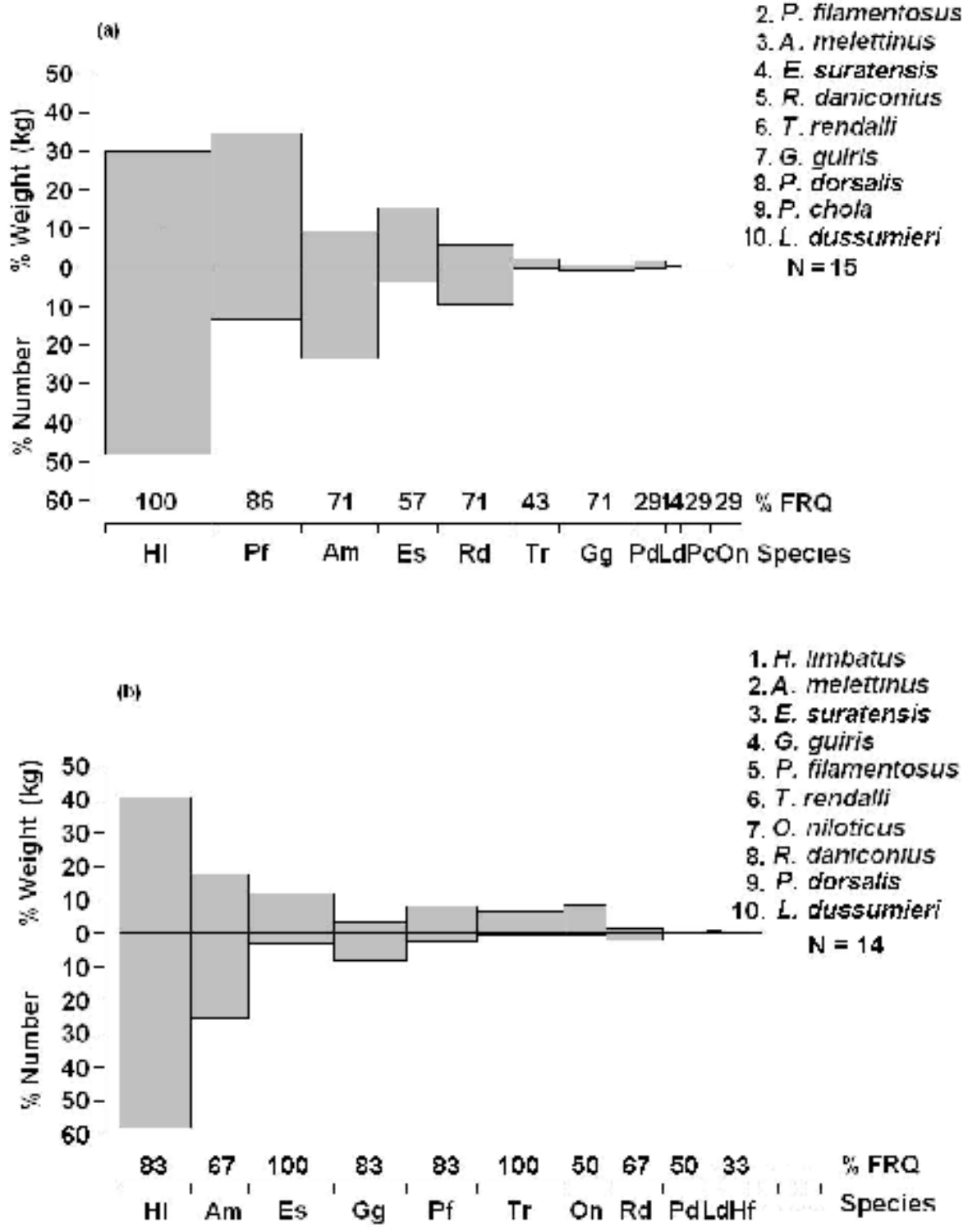

Figure 2. Relative importance of the fish species caught in shore seine nets during the seasons of high and low water level in Udawalawe reservoir. The ten most dominant fish species in the catches are listed in each figure. (a) High water level; (b) Low water level; Weight (\%) - \% CPUE; Number (\%) - \% $\mathrm{CPUE}_{\mathrm{N}} ; \% \mathrm{FRQ}$ - \% Frequency of occurrence; $\mathrm{N}$ - Number of species. For explanation of notations and terms, see the text. 

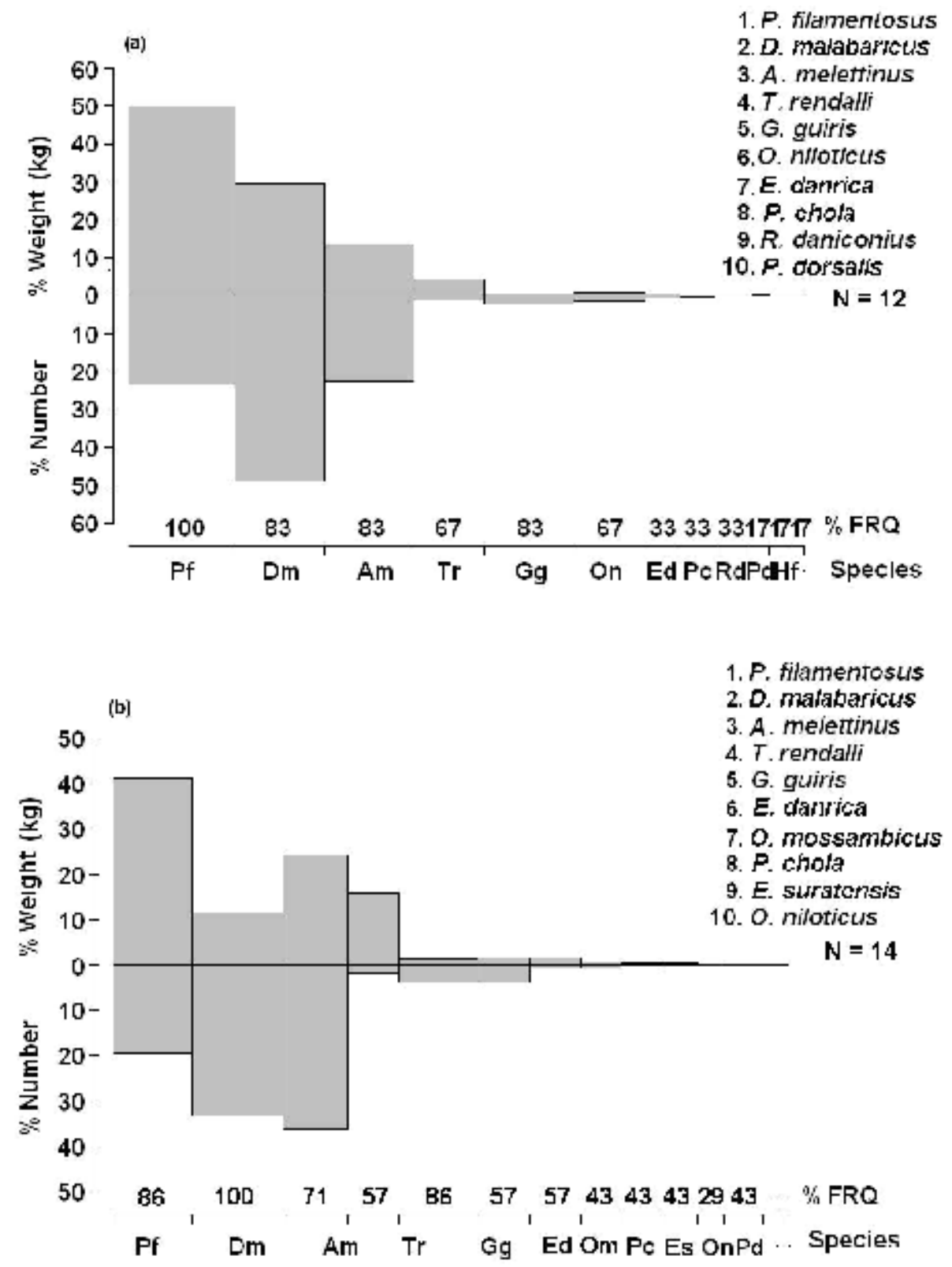

Figure 3. Relative importance of the fish species caught in shore seine nets during the seasons of high and low water level in Victoria reservoir. The ten most dominant fish species in the catches are listed in each figure. (a) High water level; (b) Low water level; Weight (\%) - \% CPUE; Number (\%) - \% $\mathrm{CPUE}_{\mathrm{N}} ; \%$ FRQ - \% Frequency of occurrence; $\mathrm{N}$ - Number of species. For explanation of notations and terms, see the text. 


\section{Discussion}

In the Sri Lankan reservoir fishery, where gillnet is the ubiquitous gear, landings are dominated by two exotic cichlid species, O. mossambicus and $O$. niloticus accounting for over $90 \%$ of the landings (Amarasinghe 1998). This is solely due to the mesh regulations imposed by fisheries authorities making $8.5 \mathrm{~cm}$ as the minimum permissible mesh size in gillnets. It is wellknown that gear type and use affect the efficiency and probability of fish capture and species composition of the catches (Gobert 1994; Dalzell 1996). In Sri Lankan reservoirs, it has been emphasized that for a more complete utilization of the biological fish production, the fish species composition in the landing has to be diversified through modification of the present exploitation pattern (Pet et al. 1996). Fishing gear types such as seine nets usually take a wide range of sizes and species (Dalzell 1996; Gell and Whittington 2002). However, the catch composition in shore seine nets essentially reflects the efficiency of shore seine nets for catching different species.

Fish species which feed on terrestrial insects when present, such as Danio malabaricus and Rasbora daniconius (Weliange and Amarasinghe 2003), were abundant during the months of high water level $P$. filamentosus was dominant in shore seine catches in Udawalawe reservoir during the months of high water level. This species is known to be aggregated in the peripheral areas of reservoirs where macrophytes are abundant (Hofer and Schiemer 1983). As there were inundated macrophytes in the littoral areas of Udawalawe reservoir during the seasons of high water level, they must have been caught in high numbers in the shore seine nets operated during these periods. In Minneriya and Udawalawe reservoirs whereH. limbatus occurs, high \%IRI during all seasons might be due to their aggregation in littoral areas of reservoirs.

H. limbatus is predominantly a zooplankton feeder and is reported to be mainly selecting the medium and larger-sized cladocerans, which are slow swimmers, and the large adult insects (Ariyaratne et al. 2008). Its aggregation in littoral zones of the two reservoirs is perhaps due to abundance of preferred food of this species.

As shown by Swain and Sinclair (1994), fish abundance is not essentially proportional to CPUE. As fish are not likely to be uniformly distributed over their range (Paloheimo and Dickie 1964), fishing in areas where fish are aggregated might result in higher CPUE than in area where fish are sparsely distributed. Swain and Sinclair (1994) emphasized that spatially uniform and non-uniform densities have different effects on catchability. Accordingly, effects of spatially uniform and non-uniform densities on catchability are referred to as effects of "abundance" and "spread" respectively (Swain and Sinclair 1994). Different magnitudes of most fish species which were caught in shore seine nets in the three reservoirs during the seasons of high and low water levels might therefore be due to the differences of their "spread" but not due to the differences in "abundance." 
Of the fish species caught in shore seine nets, $H$. limbatus was the most dominant species in the two reservoirs (Minneriya and Udawalawe) where this species is found. H. limbatus was insignificant in the catches of experimental gillnetting (Ajith Kumara et al. in press). As such, in order to establish a fishery for this under-exploited species, shore seining is the appropriate fishing strategy. However, seining is considered to be an expensive and labour-consuming fishing method for use in inland waters (Backiel and Welcomme 1980). On the other hand, Dr. J. Kubecka (pers. comm.), who has been using shore seines for sampling of fish in reservoirs of Czech Republic and several other European countries stated that when financial resources are limited, shore seining is the most cost-effective way to obtain a reasonable sample of fish communities.

The \%IRI indicates that at least one species of exotic cichlids is included within the top ten species in every reservoir during every season. As tilapias generally occupy littoral areas (Duncan and Kubecka 1995; Turner and Robinson 2000), exploitation of under-exploited species such asH. limbatus in Sri Lankan reservoir using shore seine nets has to be done with caution. Hence, such a fishery is needed to be strictly managed in order to prevent indiscriminate exploitation of exotic cichlids in Sri Lankan reservoirs, which form productive fisheries.

\section{Acknowledgements}

This study was carried out as part of a research project funded by European Union INCO-DC Programme Project Number: IC18-CT-0190. We are thankful to Drs C. Nissanka and W.S. Weliange and Messrs M.G. Ariyaratne and R.P.P.K. Jayasinghe for their assistance in shore seining.

\section{References}

Ajith Kumara, P.A.D., U.S. Amarasinghe, F. Schiemer, G. Winkler \& M. Schabuss, in press.

Distribution and abundance of unexploited fish Species in three Sri Lankan reservoirs. Asian Fisheries Science 00: 00-00.

Amarasinghe, U.S. 1985.

Studies on the exploitation of minor cyprinids in Parakrama Samudra, a man-made lake in Sri Lanka, using gillnets. Journal of the National Aquatic Resources Agency (Sri Lanka) 32: 11 -23.

Amarasinghe, U.S. 1998.

Reservoir fisheries management in Sri Lanka: Achievements, mistakes and lessons for future. International Review of Hydrobiology 83 (Special Issue): 523-530.

Amarasinghe, U.S. \& S.S. De Silva 1992.

Empirical approaches for evaluating the efficiencies of different fishing methods in tropical, shallow reservoirs: a Sri Lankan case study. In: 
Reservoir Fisheries of Asia (S.S. De Silva ed.) pp. 217-227. International

Development Research Centre, Ottawa.

Ariyaratne, M.G., P.B. Amarasinghe, N.C. Lopez, M. Kakkaew \& J. Vijverberg 2008.

Selective feeding of five species of small zooplanktivorous pelagic fish in South-east Asian reservoirs (Sri Lanka, Thailand) and Lake Taal (Philippines). In: Aquatic Ecosystems and Development: Comparative Asian Perspectives (F. Schiemer, D. Simon, U.S. Amarasinghe and J. Moreau eds). pp. 235-248. Biology of Inland W aters, Backhuys Publishers, Leiden, The Netherlands.

Backiel, T. \& R.L. Welcomme (eds) 1980.

Guidelines for sampling fish in inland waters. EIFAC Technical Paper 33: $176 \mathrm{p}$.

Caulton, M.S. 1975.

The ability of the cichlid fishes Tilapia rendalli Boulenger, Tilapia sparrmanii A. Smith and Hemihaplochromis (= Pseudocrenilabrus) philander (M. Weber) to enter deep water. Journal of Fish Biology 7: 513-517.

Caulton, M.S. \& B.J. Hill 1973.

The ability of Tilapia mossambica (Peters) to enter deep water. Journal of Fish Biology 5: 783-788.

Dalzell, P. 1996.

Catch rates, selectivity and yields of reef fishing. In: Reef Fisheries (N.V.C. Polunin and C.M. Roberts eds). pp. 161-192. Chapman \& Hall, London.

De Silva, S.S. \& H.K.G. Sirisena 1987.

New fish resources of reservoirs in Sri Lanka. Feasibility of introduction of a subsidiary gillnet fishery for minor cyprinids. Fisheries Research 6: 17-34.

Duncan, A. and J. Kubecka 1995.

Land/Water ecotone effects in reservoirs on the fish fauna. Hydrobiologia 303: 11-30.

Fernando, C.H. 1967.

The beach seine fishery in Ceylon's freshwaters. Indo-Pacific Fisheries Commission Current Affairs Bulletin 50: 1-21.

Gell, F.R. \& M.W. Whittington 2002.

Diversity of fishes in seagrass beds in the Quirimba Archipelago, northern Mozambique. Journal of Marine and Freshwater Research 53: $115-121$.

Gobert, B. 1994.

Size structures of demersal catches in a multispecies multigear tropical fishery. Fisheries Research 19: 87-104.

Hofer, R. \& F. Schiemer 1983.

Feeding ecology, assimilation efficiencies and energetics of two herbivorous fish: Sarotherodon (Tilapia) mossambicus (Peters) and Puntius filamentosus (Cuv. Et Val.). In: Limnology of Parakrama 
Samudra - Sri Lanka (F. Schiemer ed.). pp. 155-164. Dr. W. Junk Publishers, The Hague, The Netherlands.

Kolding, J. \& A. Skaalevik 2007.

Pasgear II, V ersion 2.3. University of Bergen, Department of Biology, Thormoehlensgt., Bergen, Norway. URL: www.cdcf.no/data/pasgear.

Paloheimo, J. E. \& L.M. Dickie 1964.

Anundance and fishing success. Rapport et Procés-Verbaux des Réunions. Conseil International pour Exploration de la Mer 155: 152163.

Pet, J. S. \& G. J. Piet 1993.

The consequences of habitat occupation and habitat overlap of the introduced tilapia Oreochromis mossambicus and indigenous fish species for fishery management in a Sri Lankan reservoir. Journal of Fish Biology 43 (Supplement A): 193-208.

Pet, J.S., G.J.M. Gevers, W.L.T. van Densen \& J. Vijverberg 1996.

Management options for a more complete utilization of the biological fish production in Sri Lankan reservoirs. Ecology of Freshwater Fish 5: 1-14.

Ribbink, A. J. \& B. J. Hill 1979.

Depth equilibration by two predatory cichlid fish from Lake Malawi. Journal of Fish Biology 14: 507-510.

Swain, D. P. \& A. F. Sinclair 1994.

Fish distribution and catchability: What is the appropriate measure of distribution? Canadian Journal of Fisheries and Aquatic Science 51: 1046-1054.

Turner, G. F. \& R. L. Robinson 2000.

Reproductive biology, mating systems and parental care. In: Tilapias: Biology and exploitation (M.C.M. Beveridge and B.J. McAndrew eds). pp. 33-58. Fish and Fisheries Series 25, Kluwer Academic Publishers, Dordrecht, The Netherlands.

Weliange, W. S. \& U. S. Amarasinghe 2003.

Seasonality in dietary shifts in size-structured freshwater fish assemblages in three reservoirs of Sri Lanka. Environmental Biology of Fishes 68(3): 269-282. 